\title{
Correction to: Proteoglycan-4 is an essential regulator of synovial macrophage polarization and inflammatory macrophage joint infiltration
}

\author{
Marwa Qadri ${ }^{1}$, Gregory D. Jay ${ }^{2}$, Ling X. Zhang ${ }^{2}$, Tannin A. Schmidt ${ }^{3}$, Jennifer Totonchy ${ }^{4}$ and Khaled A. Elsaid ${ }^{4^{*}}$
}

Correction to: Arthritis Res Ther 23, 241 (2021)

https://doi.org/10.1186/s13075-021-02621-9

Following publication of the original article [1], the authors reported an error as follows:

In the Authors information section, Holly Richendrfer who is not an author on the manuscript was removed. The corrected author information is listed below:

Marwa Qadri, Pharm.D., Ph.D.: Assistant Professor of Pharmacology, Jazan University School of Pharmacy, Jazan, Kingdom of Saudi Arabia.

Gregory D. Jay, MD, Ph.D.: Professor, Emergency Medicine and Engineering, Brown University, Providence, RI, USA.

Ling Zhang, MD: Senior Research Assistant, Rhode Island Hospital, Providence, RI, USA.

Tannin A. Schmidt, Ph.D.: Associate Professor of Biomedical Engineering, University of Connecticut Health Center, Farmington, CT, USA.

Jennifer Totonchy, Ph.D.: Assistant Professor of Biomedical and Pharmaceutical Sciences, Chapman University, Irvine, CA, USA.

Khaled A. Elsaid, Pharm. D, Ph.D.: Associate Professor of Biomedical and Pharmaceutical Sciences, Chapman University, Irvine, CA, USA.

\begin{abstract}
Author details
${ }^{1}$ Department of Pharmacology, College of Pharmacy, Jazan University, Jazan 82826, Kingdom of Saudi Arabia. ${ }^{2}$ Department of Emergency Medicine, Rhode Island Hospital, Providence, RI, USA. ${ }^{3}$ Biomedical Engineering Department, School of Dental Medicine, University of Connecticut, Farmington, CT, USA. ${ }^{4}$ Department of Biomedical and Pharmaceutical Sciences, Chapman University School of Pharmacy, Rinker Health Sciences Campus, 9401 Jeronimo Road, Irvine, CA 92618, USA.
\end{abstract}

Published online: 29 October 2021

\section{Reference}

1. Qadri M, Jay GD, Zhang LX, et al. Proteoglycan-4 is an essential regulator of synovial macrophage polarization and inflammatory macrophage joint infiltration. Arthritis Res Ther. 2021;23:241. https://doi.org/10.1186/ s13075-021-02621-9. permits use, sharing, adaptation, distribution and reproduction in any medium or format, as long as you give appropriate credit to the original author(s) and the source, provide a link to the Creative Commons licence, and indicate if changes were made. The images or other third party material in this article are included in the article's Creative Commons licence, unless indicated otherwise in a credit line to the material. If material is not included in the article's Creative Commons licence and your intended use is not permitted by statutory regulation or exceeds the permitted use, you will need to obtain permission directly from the copyright holder. To view a copy of this licence, visit http://creativecommons.org/licenses/by/4.0/. The Creative Commons Public Domain Dedication waiver (http://creativecommons.org/publicdomain/zero/1.0/) applies to the data made available in this article, unless otherwise stated in a credit line to the data. 